\title{
Intensive management disrupts belowground multi- trophic resources transfers in response to drought
}

Mathilde Chomel ( $\nabla$ mathilde.chomel@manchester.ac.uk)

University of Manchester https://orcid.org/0000-0001-5110-2355

Jocelyn Lavallee

University of Manchester

Nil Alvarez Segura

Eurecat Centre Tecnològic de Catalunya

\section{Elizabeth Baggs}

The University of Edinburgh https://orcid.org/0000-0003-2014-2148

\section{Tancredi Caruso}

University College Dublin

Francisco de Castro

AgriFood \& Biosciences Institute

Mark Emmerson

Queens University Belfast

Matthew Magilton

University of Lincoln

Jennifer Rhymes

Centre for Ecology and Hydrology https://orcid.org/0000-0001-9347-9863

\section{Heather Stott}

University of Manchester

\section{Franciska de Vries}

University of Manchester https://orcid.org/0000-0002-6822-8883

\section{David Johnson}

University of Manchester https://orcid.org/0000-0003-2299-2525

\section{Richard Bardgett}

University of Manchester https://orcid.org/0000-0002-5131-0127

\section{Article}

Keywords: grassland, plant-soil interaction, pulse-labelling, root-derived C, Collembola, Acari, microorganisms, soil biodiversity, stable isotope 
DOI: https://doi.org/10.21203/rs.3.rs-1283195/v1

License: (c) (1) This work is licensed under a Creative Commons Attribution 4.0 International License. Read Full License

Additional Declarations: There is NO Competing Interest.

Version of Record: A version of this preprint was published at Nature Communications on November 16th, 2022. See the published version at https://doi.org/10.1038/s41467-022-34449-5. 
1 Intensive management disrupts belowground multi-trophic resources transfers in

2 response to drought

3

4 Mathilde Chomel ${ }^{1,2^{*}}$, Jocelyn M. Lavallee ${ }^{2,3}$, Nil Alvarez-Segura1 1,4, Elizabeth M. Baggs 1 ${ }^{1,5}$,

5 Tancredi Caruso $^{6,7}$, Francisco de Castro ${ }^{6,8}$, Mark C. Emmerson ${ }^{7}$, Matthew Magilton ${ }^{7,9}$, Jennifer

6 M. Rhymes ${ }^{2,10}$, Heather Stott ${ }^{2}$, Franciska T. de Vries ${ }^{2,11}$, David Johnson ${ }^{1,2}$, and Richard D.

$7 \quad$ Bardgett $^{2}$

8

9 1. Institute of Biological and Environmental Sciences, University of Aberdeen, Cruickshank 10 Building, Aberdeen AB24 3UU, UK

11 2. Department of Earth and Environmental Sciences, The University of Manchester, 12 Manchester, M13 9PT, UK

13 3. Department of Soil and Crop Sciences, Colorado State University, Fort Collins, CO, USA

14 4. Department of Climate Change, EURECAT, Technological Centre of Catalonia, Spain

15 5. Global Academy of Agriculture and Food Security, Royal (Dick) School of Veterinary

16 Studies, University of Edinburgh, Midlothian, UK

17 6. School of Biological Sciences and Institute for Global Food Security, Queen's University of 18 Belfast, Belfast, UK

19 7. School of Biology and Environmental Science, University College Dublin, Dublin, Ireland 20 8. AgriFood \& Biosciences Institute, Belfast, UK.

21 9. School of Life Sciences, University of Lincoln, Lincoln, UK

10. Centre for Ecology and Hydrology, Environment Centre Wales, Bangor LL57 2UW, UK

23 11. Institute for Biodiversity and Ecosystem Dynamics, University of Amsterdam, the 24 Netherlands 
* Corresponding Author:

27 Mathilde Chomel, mathilde.chomel@manchester.ac.uk, +44(0)1612755959

28 Keywords: grassland, plant-soil interaction, pulse-labelling, root-derived C, Collembola, 29 Acari, microorganisms, soil biodiversity, stable isotope

Abstract

Modification of soil food webs by historical land management may alter the response of ecosystem processes to climate extremes, but empirical support for this is limited and the mechanisms involved remain unclear. Here, we quantified how historical grassland management modifies transfers of recent photosynthate and soil nitrogen through plants and soil food web in response to drought, using in situ ${ }^{13} \mathrm{C}$ and ${ }^{15} \mathrm{~N}$ pulse-labelling in paired intensively and extensively managed fields. We show that intensive management decreased plant carbon capture, its transfer through key components of food webs and soil respiration compared to extensive management. Drought only affected carbon transfer pathways in intensively managed grasslands, by increasing plant $\mathrm{C}$ assimilation but decreasing its transfer to plant roots, bacteria and Collembola. However, drought lowered the reduction of added nitrate to nitrous oxide in extensively managed grassland only. Our findings indicate that intensive management disrupts fluxes of recent photosynthates belowground, which impaired resistance of this process in response to drought. By contrast, extensive grassland management provides a greater potential to buffer impacts to drought by promoting the transfer of recent photosynthate belowground. Our work highlights that capture and rapid transfer of

47 photosynthate through multitrophic networks is a key process for maintaining grassland resilience to drought. 
All organisms within ecosystems are interlinked by energy flows in complex

52

53

54

55

56

57

58

59

60

61

62

63

64

65

66

67

68

69

multitrophic networks, and changes in the network structure modify these energy flows ${ }^{1}$.

Theoretical evidence suggests that shifts in food web structure play an important role in regulating the stability of soil functions following perturbations and impair their ability to buffer future extreme climatic events ${ }^{2-5}$. Grasslands are under threat from ongoing degradation caused by multiple co-occurring drivers, including management intensification and climate extremes ${ }^{6}$. Drought events are a recurring phenomenon in many ecosystems and are predicted to increase in frequency and intensity in the coming decades ${ }^{7,8}$. Consequently, there is a need to understand the interactions between these different drivers to inform sustainability policy aimed at protecting the multiple ecosystem services that grasslands provide ${ }^{6,9}$.

Intensive grassland management, characterised by the regular use of inorganic fertilisers and high livestock stocking densities, is known to decrease plant diversity ${ }^{10}$, decrease the abundance and diversity of arbuscular mycorrhizal (AM) fungi ${ }^{11}$ and soil biota 12,13 , and induce shifts in the composition of soil microbial communities ${ }^{12-14}$. Such changes have important consequences for biogeochemical cycles because soil food webs associated with agricultural intensification, including shifts in the relative abundance of bacterial and fungal energy channels, are often linked with faster nutrient mineralisation rates, which could potentially contribute to greater losses of carbon $(\mathrm{C})$ and nitrogen $(\mathrm{N})$ from soil ${ }^{15-18}$. A critical gap in our knowledge concerns how shifts in food web structure and the relative abundance of fungi and bacteria modulate transfers of $\mathrm{C}$ from plants to below ground pools and fluxes, and the capture of growth-limiting nutrients by plants from soil energy channels.

Recent empirical studies indicate that intensive management can decrease the resistance to drought of plant productivity and soil respiration ${ }^{19,20}$ of soil food web biomass ${ }^{19}$, and of C allocation to soil microbial communities ${ }^{21}$. However, it is becoming apparent that the stability of ecosystem functions in response to perturbations can only be understood if multiple trophic 
76 levels and interactions among them are considered ${ }^{22,23}$. As such, there is a need to study the

77 role of food web structure from a multitrophic perspective, including plants and belowground 78 organisms, in modulating the response of processes of $\mathrm{C}$ and $\mathrm{N}$ loss to perturbations, such as 79 drought. Furthermore, while there is growing awareness of the importance of rhizodeposition 80 as a driver of belowground energy flow and the structure and functions of soil food webs ${ }^{24-29}$, 81 it remains unclear how the resilience of this process to perturbations, such as drought, responds 82 to changes in land use. These two major gaps in our knowledge are essential to facilitate 83 reliable predictions of soil $\mathrm{C}$ and $\mathrm{N}$ cycling and sequestration in response to dual pressures of 84 agricultural intensification and increased frequency and intensity of climate extremes. We hypothesised that : (1) extensive grassland management promotes the transfer of photosynthetic C from plants to AM fungi and the decomposer food web, thereby lowering C and $\mathrm{N}$ losses as greenhouse gases $\left(\mathrm{CO}_{2}\right.$ and $\left.\mathrm{N}_{2} \mathrm{O}\right)$ and buffering $\mathrm{C}$ and $\mathrm{N}$ fluxes against drought; and (2) intensive management disrupts this coupling of C flow from plants to the soil food web, leading to greater soil $\mathrm{C}$ and $\mathrm{N}$ losses as $\mathrm{CO}_{2}$ and $\mathrm{N}_{2} \mathrm{O}$ and reduced resistance of $\mathrm{C}$ and $\mathrm{N}$ fluxes to drought.

We tested these hypotheses by simulating summer drought using rainfall shelters on paired extensively and intensively managed mesotrophic grasslands across three geographically distinct locations in northern England. In both control and drought plots, plant communities and soil food web (microorganisms and mesofauna) biomass and composition were determined. To investigate the short-term allocation of $\mathrm{N}$ and recently assimilated $\mathrm{C}$ belowground, we pulse-labelled plants with ${ }^{13} \mathrm{C}-\mathrm{CO}_{2}$, and soil with ${ }^{15} \mathrm{~N}-\mathrm{NO}_{3}$ at the end of the simulated drought. We traced the incorporation of ${ }^{13} \mathrm{C}$ and ${ }^{15} \mathrm{~N}$ into plant shoot and roots, microbial biomarkers, soil mesofauna and soil $\mathrm{CO}_{2}$ and $\mathrm{N}_{2} \mathrm{O}$ fluxes over a 20-day period.

\section{Materials and methods}


102 The field experiment was carried out in 2016 across a series of mesotrophic grasslands located 103 in the Yorkshire Dales, northern England (mean annual temperature $7.3^{\circ} \mathrm{C}$, mean annual precipitation $1382 \mathrm{~mm}$ ). Three geographically distinct sites were selected, each with adjacent, paired grasslands (field) with a long term ( $>20$ years) history of intensive or extensive grassland management on the same soils and of similar topography (see Table S1 for more details). Extensively managed grasslands had not received any additions of inorganic fertiliser and had been grazed at low stocking densities by sheep or cattle (typically grazed at $<1$ livestock unit $\left.\mathrm{ha}^{-1} \mathrm{y}^{-1}\right){ }^{30}$. Intensively managed grasslands received $>100 \mathrm{~kg} \mathrm{~N} \mathrm{ha}^{-1} \mathrm{y}^{-1}$ and were grazed at high stocking densities or for longer (typically grazed at 2-3.5 livestock unit ha- $\mathrm{y}^{-1}$ ) ${ }^{30}$, and

111 were cut for hay once a year ${ }^{30}$. In general, plant communities of the extensively managed grasslands were species-rich Anthoxanthum odoratum-Geranium sylvaticum hay meadows

113 (MG3 or subcategories), whereas plant communities of intensively managed grasslands were

114 species-poor and classified as Lolium perenne-Cynosurus cristatus (MG6, MG7, and subcategories), according to the UK National Vegetation Classification ${ }^{31}$. The soils were all humose loamy brown earth ( $\mathrm{pH} \sim 5.47 ; 11.4 \%$ total $\mathrm{C} ; 0.76 \%$ total $\mathrm{N})$.

Drought was simulated by placing three transparent roofs $(1.5 \mathrm{~m} * 1.3 \mathrm{~m})$ alongside

118 delimited control plots in each field for 60 days (17-19 of May - 17-19 of July 2016) designed 119 to simulate a 100-year drought event ${ }^{32}$. In each plot a $40 \mathrm{~cm}$ metallic collar (hereafter "subplot") was inserted into the first $7 \mathrm{~cm}$ of soil before the treatment was initiated. At the centre of this collar a smaller plastic collar of $11 \mathrm{~cm}$ diameter was inserted and vegetation inside it was clipped to allow measurement of gas fluxes from the soil only. After the removal 123 of the shelters, each plot (control and drought) received four litres of water to release the

124 drought and encourage photosynthetic activity and the isotopic labelling started as detailed 125 below. 


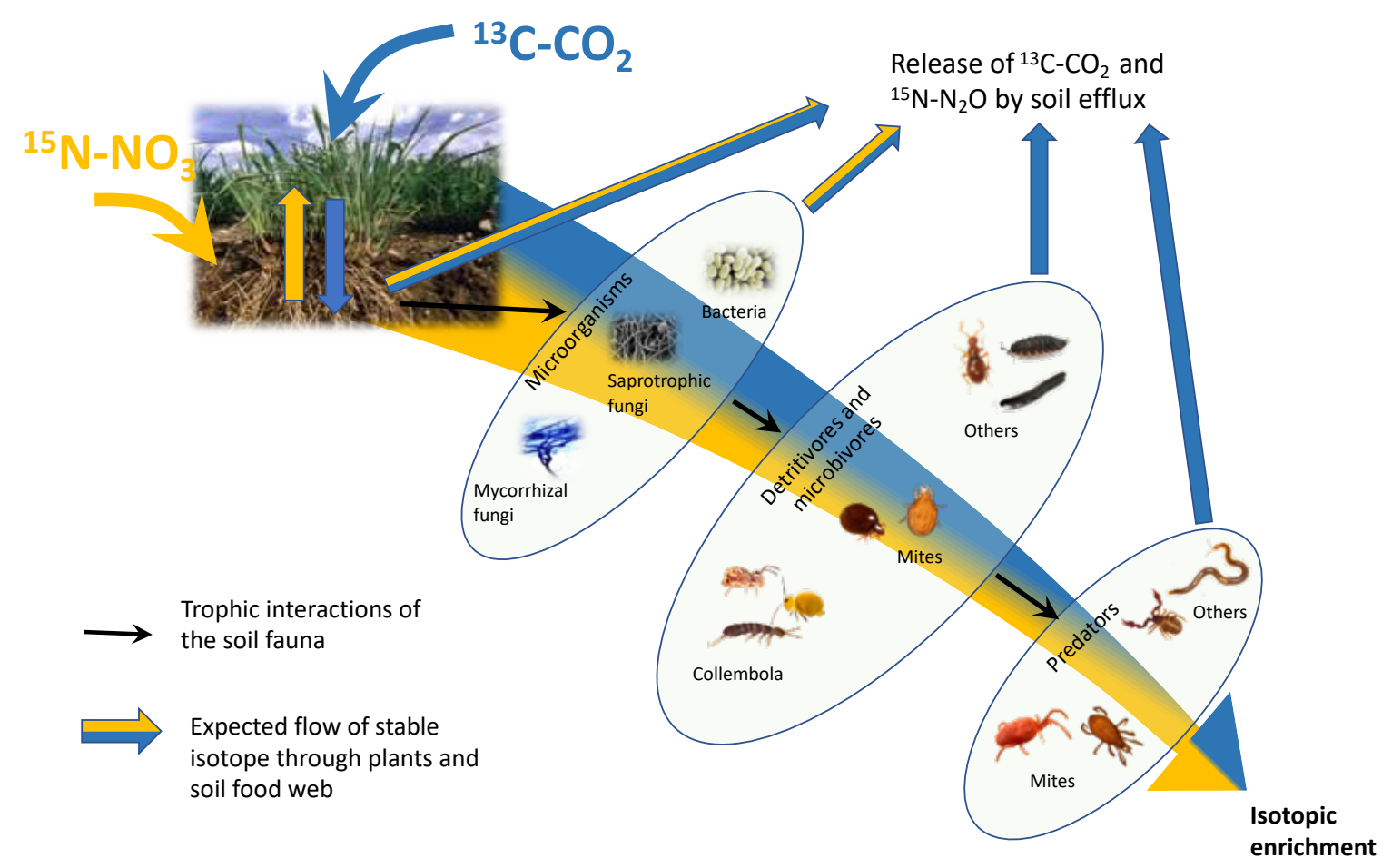

Figure 1. Conceptual diagram of the grassland soil food web of this study with representation of the expected flow of ${ }^{13} \mathrm{C}$ (blue) and ${ }^{15} \mathrm{~N}$ (yellow) through plants and trophic groups. The arrows represent resource transfer between trophic groups. The isotopic enrichment is expected to decrease at higher trophic levels of the food web. Pictures of soil mesofauna from P. Lebeaux (www.animailes.com) and M. Chomel. community (microorganisms and mesofauna) and back to the atmosphere as $\mathrm{CO}_{2}$ and $\mathrm{N}_{2} \mathrm{O}$ emissions across a period of 20-days (Fig. 1). Five hours after the end of the drought, $130 \mathrm{ml}$ of a solution of $\mathrm{NH}_{4}{ }^{-15} \mathrm{NO}_{3}$ (Nitrate- ${ }^{15} \mathrm{~N}, 98$ atom\%; CK Isotopes Ltd, Leicestershire, UK) was applied directly into the first $7 \mathrm{~cm}$ of soil with a side-hole needle by injecting into 20 locations within the subplots. The quantity injected was equivalent to the annual $\mathrm{N}$ deposition in the UK 
141 (20 kg N ha-1). Three hours later, a composite soil sample was taken consisting of $3 \mathrm{x} 1 \mathrm{~cm}$

142 diameter cores from each subplot. The following morning, vegetation in the same subplots 143 were labelled with 99 atom $\%{ }^{13} \mathrm{C}_{-} \mathrm{CO}_{2}$ (Sigma aldrich). We used an air-tight chamber 144 constructed with a plastic bell cloche (approx. 20 L) equipped with 2 small fans to disperse the 145 gas, and a rubber septum at the top to inject the gas. Prior to the start of the ${ }^{13} \mathrm{C}$ labelling ca. 10:00 GMT, the photosynthetic rate was measured using an infrared gas analyser (EGM-4, PP

147 Systems, Hitchin, UK) to determine the timing of the $\mathrm{CO}_{2}$ injections. During approximately 21483 hours, $25 \mathrm{~mL}$ of ${ }^{13} \mathrm{C}-\mathrm{CO}_{2}$ were regularly injected through the septum for a total of $250 \mathrm{ml}$ per 149 subplot. The twelve subplots within a site (i.e. both extensive and intensive management 150 regimes) were labelled at the same time. The three sites were labelled over 3 consecutives days for logistical reasons. small soil cores ( $1 \mathrm{~cm}$ diameter), and gas samples were taken from each plot. At 1, 2, 5, 10 and 20 days after the ${ }^{13} \mathrm{C}-\mathrm{CO}_{2}$ pulse labelling, gas samples were taken and a fifth of the soil from the subplots (metal ring) was harvested (Figure S1). We refer to day 1 as being approximately $24 \mathrm{~h}$ after ${ }^{13} \mathrm{C}$ labelling and $36 \mathrm{~h}$ after ${ }^{15} \mathrm{~N}$ addition. The holes created were filled back with sand to minimise gas exchange from the exposed surface and disturbance. Four supplementary cores outside the plots were taken per field to determine the ${ }^{13} \mathrm{C}$ and ${ }^{15} \mathrm{~N}$ natural abundance signatures of each $\mathrm{C}$ and $\mathrm{N}$ pool. Plants were divided into shoot and root fractions, washed (for the roots fractions only), oven dried at $60^{\circ} \mathrm{C}$ and weighed prior to analysis. All samples were analysed for total $\mathrm{C}$ and $\mathrm{N}$ content and $\delta^{13} \mathrm{C}$ and $\delta^{15} \mathrm{~N}$ signatures using an elemental analyser (PDZ Europa ANCA-GSL,

163 Sercon Ltd, Crewe, UK) coupled to a 20-20 isotope ratio mass spectrometer (Sercon Ltd, 164 Crewe, UK). A portion of soil was sieved and freeze dried prior to the PLFA extractions. From 
the remaining soil, mesofauna were extracted using Tullgren funnels over 7 days and stored in $70 \%$ ethanol.

\section{Soil microbial community analysis}

169 Soil microbial communities were characterised by the extraction of the phospholipid fatty acids

170 (PLFAs), according to Buyer and Sasser method ${ }^{33}$. Details of the method can be found in

171 Chomel et al. (2019). The $\delta^{13} \mathrm{C}$ signatures of individual PLFAs and their quantification were

172 analyzed by GC-C-IRMS using a GC Trace Ultra with combustion column attached via a GC

173 Combustion III to a Delta V Advantage IRMS (Thermo Finnigan, Bremen, Germany; Thornton

174 et al. 2011). The internal standard 19:0 phosphati- dylcholine (Avanti Polar Lipids) added at 175 the beginning of the extraction procedure was used for calculating concentrations. In summary,

17636 PLFAs were identified in these samples, of which 20 microbial specific PLFAs comprising 177 approximately $80 \%$ of the total concentration were used in subsequent data analysis. The fatty 178 acids i15:0, a15:0, i16:0 and i17:0 were used as biomarkers for Gram positive bacteria; 16:1 $\omega 7$,

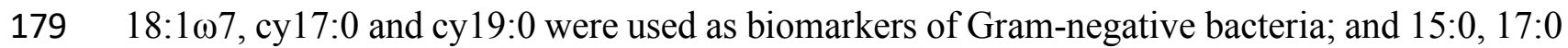
180 were used as general bacterial markers ${ }^{34}$. The fatty acids $10 \mathrm{Me17}: 0$ and 10Me18:0 were used

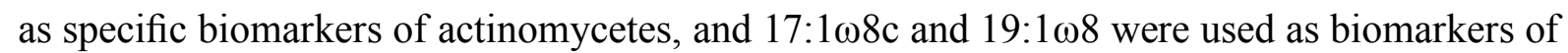
methane oxidizing bacteria ${ }^{34}$. Gram-positive, Gram-negative, and general bacterial markers

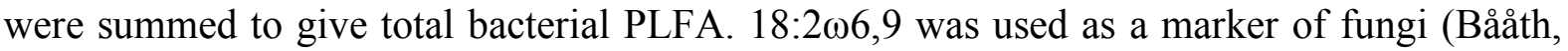
2003; Bååth and Anderson, 2003) and 16:1 15 was used as a marker of AM fungi ${ }^{35}$. Although 16:1 $1 \omega 5$ is used widely for estimating AM fungal biomass, its use can lead to uncertainties because bacteria can contribute to this pool ${ }^{35}$. However, in our case, the ${ }^{13} \mathrm{C}$-enrichment of this PLFA was very distinct from all bacterial PLFAs, which gave confidence in its use to estimate

188 AM fungal biomass and its ${ }^{13} \mathrm{C}$ uptake. The $\delta^{13} \mathrm{C}$ value of each PLFA molecule was corrected 189 for the $\mathrm{C}$ added during derivatization using the formula 


$$
\delta^{13} C_{P L F A}=\frac{C_{F A M E} \times \delta^{13} C_{F A M E}-C_{M e O H} \times \delta^{13} C_{M e O H}}{C_{P L F A}}
$$

191

where $\mathrm{C}_{\mathrm{FAME}}, \mathrm{C}_{\mathrm{MeOH}}$, and $\mathrm{C}_{\mathrm{PLFA}}$ denote the number of carbon atoms in the FAME, methanol, and PLFA, respectively, and $\delta^{13} \mathrm{C}_{\mathrm{FAME}}$ and $\delta^{13} \mathrm{C}_{\mathrm{MeOH}}$ are the measured ${ }^{12} \mathrm{C} /{ }^{13} \mathrm{C}$ isotope ratios of the FAME and methanol, respectively (methanol $\delta^{13} \mathrm{C}=-29.3 \%$ ). While the fungi are represented by only one PLFA, the bacterial community is represented by several PLFAs. To calculate an overall ${ }^{13} \mathrm{C}$-enrichment (atom\% excess) of bacterial PLFA, the net ${ }^{13} \mathrm{C}$ of all individual bacterial PLFA were summed and divided by the sum of the net $\mathrm{C}$ of all individual bacterial PLFA using the following equation:

$$
\text { Atom } \%{ }^{13} C_{\text {BacterialPLFA }}=\frac{\sum\left(C_{P L F A_{i}} \times \text { atom } \%{ }^{13} C_{P L F A_{i}}\right)}{\sum C_{P L F A i}}
$$

Where $C_{\text {PLFAi }}$ is the amount of carbon from individual PLFA and atom $\%{ }^{13} \mathrm{C}_{\mathrm{PLFAi}}$ is the ${ }^{13} \mathrm{C}$ enrichment of the individual PLFA.

\section{Mesofauna}

Individuals were counted and identified under a dissecting microscope to order and trophic group for Collembola ${ }^{36}$ and Acari ${ }^{37}$. Other invertebrates were separated according to taxa and trophic group. The biomass of each order/taxa was estimated by measuring the average body length (mm) per field, using the formula by Caruso and Migliorini ${ }^{38}$ for the mites and by Ganihar ${ }^{39}$ for the other orders. The samples were further grouped into 7 main trophic groups in order to have sufficient material to analyse ${ }^{13} \mathrm{C}$ and ${ }^{15} \mathrm{~N}$ : detritivorous Collembola, detritivorous mites (oribatid, astigmata and prostigmata mites), annelids, other detritivorous (detritivorous coleoptera, myriapoda and diptera larvae), herbivores (hemiptera and thysanoptera) predaceous mites (mesostigmata and predaceous prostigmata) and predaceous fauna (arachnida, chilopoda, predatory coleoptera and symphyla). Each of these groups was transferred into a tin capsule in $70 \%$ ethanol, oven-dried and weighed prior to analysis. All the 
samples were analysed for total $\mathrm{C}$ and $\mathrm{N}$ content and $\delta^{13} \mathrm{C}$ and $\delta^{15} \mathrm{~N}$ using a Flash EA 1112 spectrometer (Thermo Finnigan, Bremen, Germany).

\section{Gas samples}

219 Gas samples were taken by placing a $1.2 \mathrm{~L}$ dark chamber over the gas sampling core. Immediately after the closure of the chambers, and after 10, 20, and 30 minutes, $15 \mathrm{~mL}$ gas samples were taken from the headspace of the chamber using a gas-tight syringe fitted with an SGE syringe valve and transferred into pre-evacuated $12 \mathrm{~mL}$ gas-tight vial (Labco Ltd. UK). At the last time point, an additional $120 \mathrm{~mL}$ gas sample was taken and stored in an He-flushed, pre-evacuated $120 \mathrm{ml}$ gas bottle fitted with Silicone/PTFE septa (Supelco) for ${ }^{15} \mathrm{~N}_{-} \mathrm{N}_{2} \mathrm{O}$ analysis. $\mathrm{CO}_{2}$ and $\mathrm{N}_{2} \mathrm{O}$ concentrations were analysed on all samples in a gas chromatograph 7890A GC (Agilent Technologies, USA) configured with a single channel using two detectors, an FID and a micro-ECD. The $\delta{ }^{13} \mathrm{C}$ values of the samples from the last sampling point were analysed on a Picarro G2131-i Isotope and Gas Concentration Analyser (cavity ringdown spectrometer). The $\delta^{15} \mathrm{~N}$ values of the samples from the last sampling point were analysed using a Sercon Ltd isotope ratio mass spectrometer following cryofocusing in an ANCA TGII gas preparation module (Sercon Ltd, Crewe, UK).

\section{${ }^{13} \mathrm{C}$ and ${ }^{15} \mathrm{~N}$ calculations}

234 The isotopic concentration data was converted from $\delta^{13} \mathrm{C}$ and $\delta^{15} \mathrm{~N}$ values (\%) to atom \% excess ${ }^{13} \mathrm{C}$ and ${ }^{15} \mathrm{~N}$ by subtracting the atom $\%{ }^{13} \mathrm{C}$ and atom $\%{ }^{15} \mathrm{~N}$ of unlabelled controls from each enriched sample ${ }^{40} \cdot{ }^{13} \mathrm{C}$ - and ${ }^{15} \mathrm{~N}$-enrichment is independent of the pool size and is

237 indicative of the replacement of $\mathrm{C}$ or $\mathrm{N}$ from the pool by newly incorporated plant-derived ${ }^{13} \mathrm{C}$ or fertiliser-derived ${ }^{15} \mathrm{~N}$. 
Although the plants were pulse-labelled with the same amount of ${ }^{13} \mathrm{C}-\mathrm{CO}_{2}$, differences in photosynthetic and respiration rates caused the initial amount of ${ }^{13} \mathrm{C}$ fixed to differ among 241 subplots. To compare the relative transfer of ${ }^{13} \mathrm{C}$ from the plant shoot into belowground $\mathrm{C}$ pool 242 (roots, microorganisms and soil fauna) in the different systems, the results were expressed as a 243 percentage of the initial plant shoot ${ }^{13} \mathrm{C}$ enrichment. The net incorporation of the ${ }^{13} \mathrm{C}$ or ${ }^{15} \mathrm{~N}$ tracer into the different carbon/nitrogen pools

245 for each subplot was calculated as:

$$
\mathrm{Net}^{13} \mathrm{C} \text { pool }=\mathrm{C} \text { pool } \times \text { atom } \%{ }^{13} \mathrm{C} \text { pool }
$$

247 where $\mathrm{C}$ pool is the amount of $\mathrm{C}$ in each pool ( $\mathrm{gC}$ per subplot) and atom $\%{ }^{13} \mathrm{C}$ pool is the atom $248 \%$ excess of ${ }^{13} \mathrm{C}$ of each pool. The same equation is used for the net incorporation of the ${ }^{15} \mathrm{~N}$, 249 replacing ${ }^{13} \mathrm{C}$ and $\mathrm{C}$ by ${ }^{15} \mathrm{~N}$ and $\mathrm{N}$. In order to evaluate the recovery of the stable isotopes in the system, we calculated the fraction of the isotope in the different compartments as the ratio of the net incorporation amount in a compartment relative to the total initial uptake of ${ }^{13} \mathrm{C}$ by

252 the plant shoot or the total ${ }^{15} \mathrm{~N}$ label injected in the soil. These were calculated only for the 253 relevant time point for which the enrichment was maximal: at day 1 for the plant and microorganisms and at day 5 for the soil fauna.

Data analysis

257 All analyses were performed using R software (version 4.1.0. R core Team, 2017). To assess

258 the role of land management in driving the soil properties and plant biomass, we performed a 259 principal component analysis (PCA). Principal coordinates analysis (PCoA) was applied to estimate the soil community structure using Bray-Curtis dissimilarities based on Hellinger

261 transformed community data ${ }^{41}$. A permutational multivariate analysis of variance 262 (PERMANOVA) ${ }^{42}$ was performed with 999 permutations to assess whether there were 263 significant differences among grassland management. Distance comparisons in 
PERMANOVA can be sensitive to between-group differences in dispersions, so we used PERMDISP ${ }^{43}$ to determine whether the dispersions of each group around their group centroid were significantly different from one another.

To analyse the effect of land management on plant and soil organisms biomasses we used a mixed model with time and site as crossed random effects on data from control plots only ${ }^{44}$.

To analyse the effect of land management on the ${ }^{13} \mathrm{C}$ - and ${ }^{15} \mathrm{~N}$-enrichment we used a mixed model with site as random effect and allowed different variance for each time point 272 (with the function weights=varIdent(1|time)).

To quantify drought impacts, and its interaction with grassland management, we used an effect size calculated as the $\log$ Response Ratio $(\log R R)$, which quantifies the proportional difference between mean ${ }^{13} \mathrm{C}$ - or ${ }^{15} \mathrm{~N}$-enrichment in control and drought conditions ${ }^{45}$. On a log scale, an effect size of 0 means there is no difference, a positive value means a positive effect of drought, while a negative $\log R \mathrm{R}$ means a negative effect of the drought. To increase robustness, and because the trend of the response variable over time was relatively similar, we used the average value of each replicate over time in our calculation of $\log R R$. We then performed a t-test against a mean of 0 .

282 Results

1) Grassland management, soil food web composition and soil functioning

Land management modified plant communities and soil properties, with greater aboveground plant biomass, soil $\mathrm{pH}$, nitrate concentration, and bulk density, and lower water holding capacity and belowground plant biomass in intensively managed grasslands compared to extensively managed grasslands (Fig S2). The influence of land management on soil $\mathrm{CO}_{2}$ efflux was not consistent through the sampling period (interaction management*time, $\mathrm{F}=2.86, \mathrm{P}=$ 
0.0162, Fig S3), with higher $\mathrm{CO}_{2}$ efflux in extensively managed compared to intensively managed grassland at time 0 and the opposite at day 20 (Fig S3). There was a trend of higher soil $\mathrm{N}_{2} \mathrm{O}$ efflux in extensively managed grassland compared to intensively managed grassland on the first day after the pulse labelling, but this was not significant (interaction

293 time*management, $P=0.08$, Fig S3)

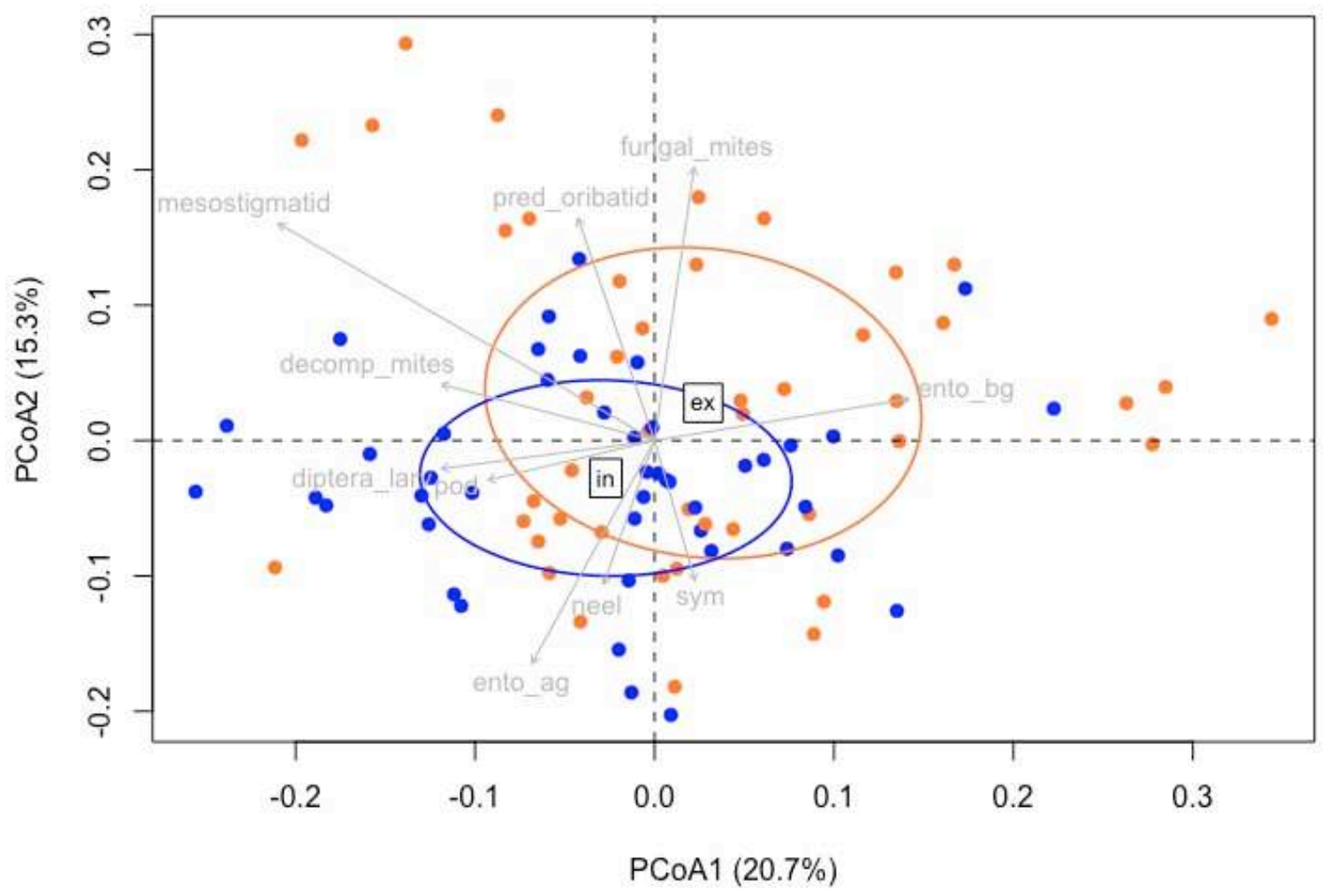

294

295 Figure 2. Principal coordinates analysis (PCoA) of soil food web communities from grasslands

296 with different land management (extensive in orange, intensive in blue). The PCoA was based on Bray-Curtis distance using soil mesofauna abundances (individuals $m^{-2}$ ) and PLFA biomass

$298\left(\mathrm{~g} \mathrm{~m}^{-2}\right)$. Grey arrows show the correlation vectors of the variables with the ordination.

299 Significance was tested by Monte Carlo permutation against 999 random datasets and 300 variables with $P>0.05$ were kept (see table $S 2$ ). 
301 Collembola was the most abundant group $\left(30,949 \pm 3,718\right.$ ind. $\mathrm{m}^{-2}, 80 \%$ were within the 302 entomobryomorpha group), followed by detritivorous mites $\left(25,114 \pm 2,772\right.$ ind. $\mathrm{m}^{-2}, 88 \%$ were 303 oribatids) and predatory mites $\left(20,094 \pm 2,279\right.$ ind. $\left.\mathrm{m}^{-2}\right)$. Soil community composition differed 304 significantly between extensive and intensive grassland (PERMANOVA, $\mathrm{F}=5.12, P<0.001$ ). 305 Despite this finding, there was substantial overlap in community composition (Fig. 2) and we 306 detected significant differences in the distribution of data, with more dispersion in soil 307 communities in extensive grassland (PERMISP, $\mathrm{F}=9.1, P=0.033$ ). With the soil fauna pooled 308 by trophic groups, the biomass of detritivorous mites (mainly Oribatids) was smaller ( $\mathrm{F}=7.03$, $309 P=0.0096$ ), while the biomass of other decomposers (mainly diptera larvae) was greater $310(\mathrm{~F}=9.08, P=0.0034)$ in intensively managed compared to extensively managed grasslands 311 (Figure S4). Intensive management did not have a significant impact on bacterial, fungal, AM 312 fungal and actinobacteria biomass, nor the fungal/bacterial ratio across grassland sites (Fig S4). 

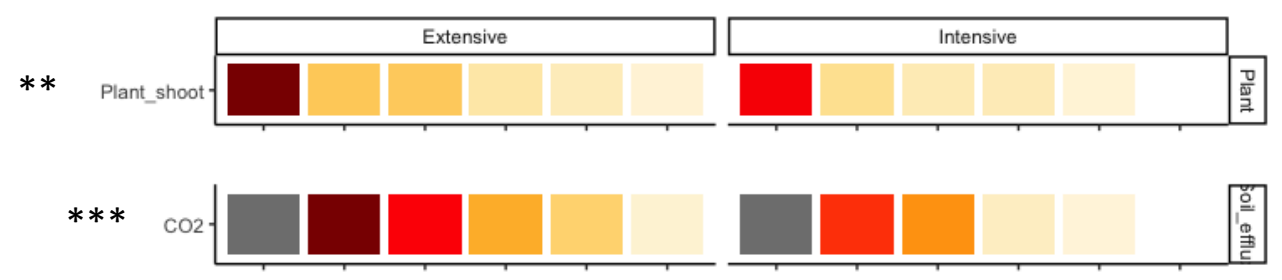

relative $13 \mathrm{C}$ enrichment
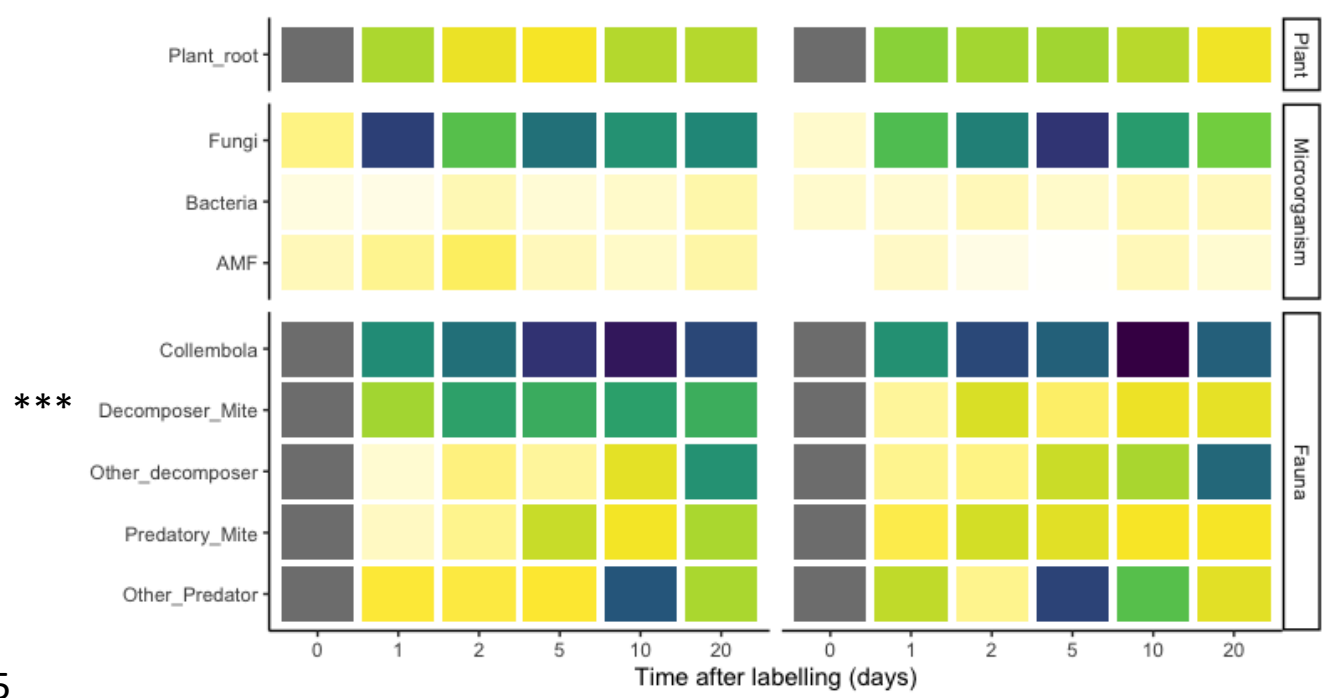

$10 \quad 20 \quad 30$

relative $13 \mathrm{C}$ enrichment

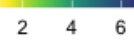

Figure 3 Temporal dynamics of ${ }^{13} \mathrm{C}$ in the plant shoot (upper panel), $\mathrm{CO}_{2}$ (middle panel) and

317 belowground pools (lower panel) following ${ }^{13} \mathrm{C}$ pulse labelling of plant shoots (time 0). The

318 heat map shows the ${ }^{13}$ C-enrichment in different pools and fluxes in grassland under extensive

319 (left) or intensive (right) management. The plant shoot enrichment is expressed in atom\%

320 excess; to be able to compare the flux of $C$ from the plant to belowground, all the other

321 variables are expressed relative to the initial ${ }^{13} \mathrm{C}$ fixed by the plants (relative ${ }^{13} \mathrm{C}$ enrichment,

$322 \%$. Note difference in scales to visualise the relative enrichments. Results of the effect of the

323 grassland management are reported with $* * * P<0.01$, $* * P<0.01$, $* P<0.05$, see Table S2

324 for details. Grey colour indicates no data available. 

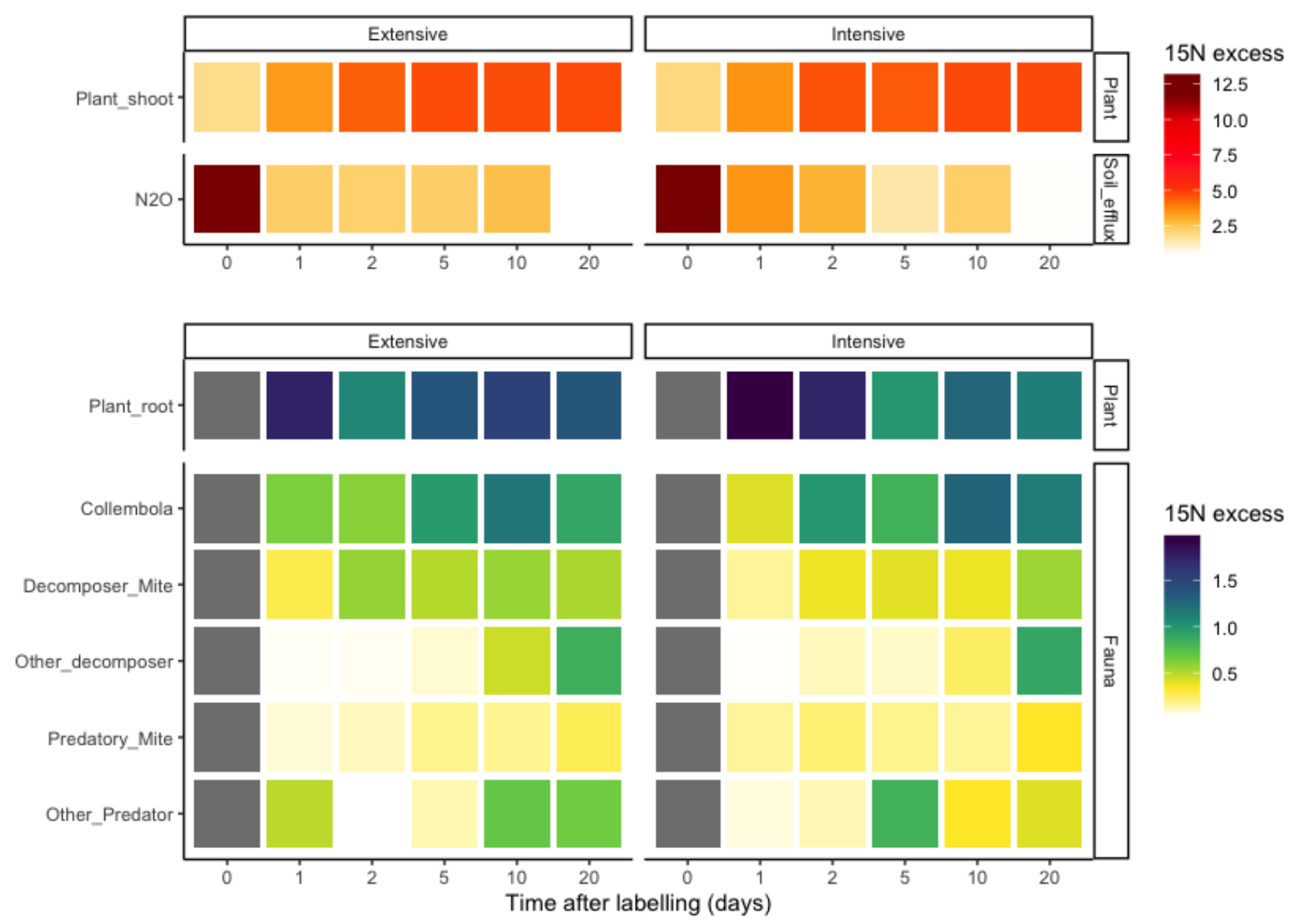

$15 \mathrm{~N}$ excess

326 Figure 4 Temporal dynamics of ${ }^{15} \mathrm{~N}$ atom \% excess aboveground (upper panel) and

327 belowground (lower panel) in plant and soil fauna following ${ }^{15} \mathrm{~N}$ pulse labelling. The heat map

328 shows the ${ }^{15} \mathrm{~N}$ atom \% excess in the different groups in grassland under extensive (left) or

329 intensive (right) management. The two panels have different scales as the enrichment of

330 aboveground nitrogen pools and fluxes is substantially greater than any of the below ground

331 pools. There were no significant effects of grassland management: see Table S3 for statistical

332 results. Grey colour indicates no data available.

334 Plant leaves in the intensively managed grassland were significantly less enriched in ${ }^{13} \mathrm{C}$,

335 consistently across the three sites, than in extensively managed grassland (Fig. 3, $P=0.015$ ).

336 The maximum ${ }^{13} \mathrm{C}$-enrichment in plant shoots occurred at the end of the labelling period and

337 was (on average) 0.55 and 0.39 atom $\%$ excess in extensively and intensively managed

338 grassland, respectively. The enrichment decreased substantially 1 day after labelling to an 
average of 0.13 and 0.11 atom $\%$ excess (Fig. 3). The uptake of ${ }^{15} \mathrm{~N}$ in plant shoots was unaffected by grassland management, but increased gradually over two days after the labelling

341 and reached a plateau of 4.5-5 atom \% excess (Fig 4). Land management had no detectable 342 influence on the ${ }^{13} \mathrm{C}$ - or ${ }^{15} \mathrm{~N}$-enrichment of plant roots (Fig. 4 and 5). Among microorganisms, fungi had the highest enrichment of ${ }^{13} \mathrm{C}$, whereas among soil

344 fauna, Collembola had the highest enrichment of ${ }^{13} \mathrm{C}$ (Fig. 3). ${ }^{13} \mathrm{C}$ enrichment was greatest in 345 AM fungi and detritivorous mites in extensively managed compared to intensively managed 346 grassland (Fig 3, $P<0.05$, see Table S3). No management effects on ${ }^{15} \mathrm{~N}$ enrichment of soil 347 fauna were detected (Fig. 4, $P>0.05$, see Table S3). Although there was a greater ${ }^{13} \mathrm{C}$ 348 enrichment of the soil $\mathrm{CO}_{2}$ efflux in extensively managed compared to intensively managed grassland $\left(P<0.001\right.$, Fig 4 , Table S3), no difference in ${ }^{15} \mathrm{~N}$-enrichment of $\mathrm{N}_{2} \mathrm{O}$ emissions was detected.

\section{3) Effect of land management on the response of $C$ and $N$ flow to drought}

353 During the rain exclusion, soil moisture was reduced on average by $56 \pm 0.4$ vol. \% in 354 intensively managed grassland and $74 \pm 0.4$ vol. $\%$ in extensively managed grassland over the 355 last 27 days recorded (Fig S1).

356 In intensively managed grassland, the drought increased the biomass of microbial 357 communities and of detritivorous mites, but reduced the biomass of plant shoots and of other 358 detritivores (Fig. S5). In extensively managed grassland, the drought increased the biomass of 359 detritivorous mites and predatory mites, but decreased the abundance of actinobacteria PLFA 360 and biomass of Collembola (Fig. S5). 
A

$$
\text { Management } \rightarrow \text { Extensive } \rightarrow \text { Intensive }
$$

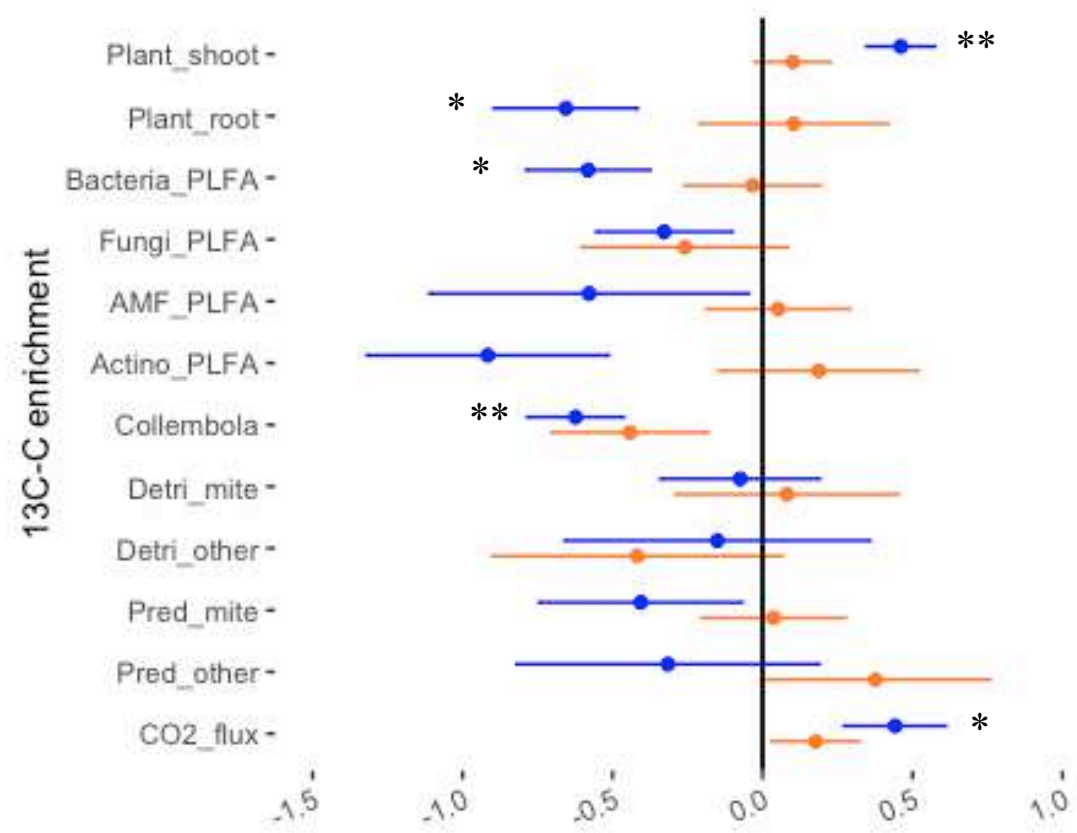

B

Plant_shoot-

Plant root -

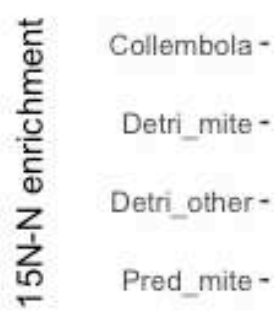

Pred_other-

N2O_flux $-1.5$

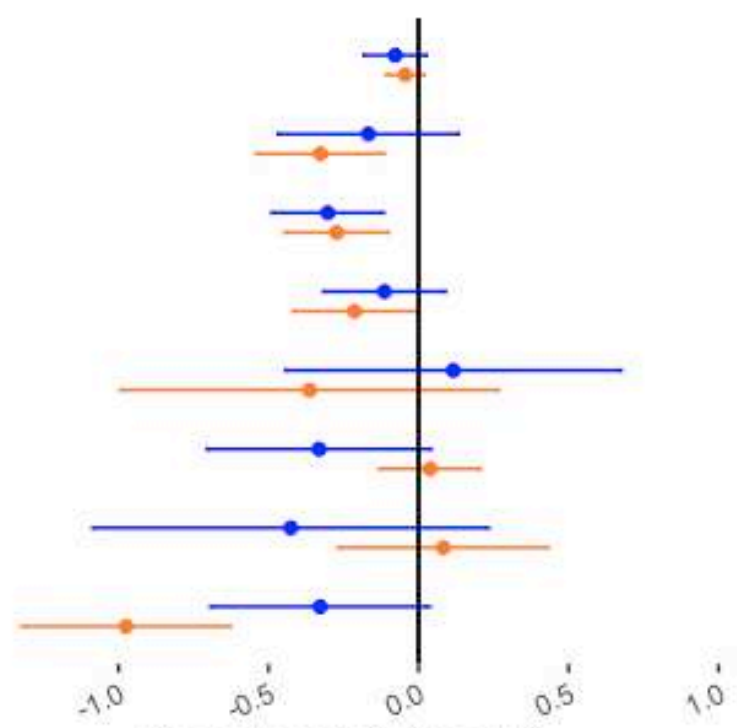

Response Ratio $(\log d / c)$

362 Figure 5. Response ratio of the drought effect on the ${ }^{13} \mathrm{C}(\mathrm{A})$ or ${ }^{15} \mathrm{~N}(\mathrm{~B})$ enrichment of the 363 different pools in function of the grassland management (log (drought/control)). The sign 364 (positive or negative) of the logRR corresponds to the direction of the drought effect on the ${ }^{13} C$ 365 or ${ }^{15} \mathrm{~N}$ enrichment, while a response ratio of zero indicates no drought effect. LogRR 366 significantly different from 0 are reported with $* * * P<0.01, * * P<0.01, * P<0.05$, see table 367 S4 for details. 
369 In extensively managed grassland, drought had no detectable effect on the uptake of ${ }^{13} \mathrm{C}$ by 370 plants, its transfer to roots and the soil food web, or soil ${ }^{13} \mathrm{C}-\mathrm{CO}_{2}$ efflux (Fig. 5, Table S4).

371 However, in intensively managed grassland, drought increased plant shoot ${ }^{13} \mathrm{C}$ enrichment (Fig.

3725 , Table S4. $P=0.004)$ and ${ }^{13} \mathrm{C}$ relative enrichment of soil $\mathrm{CO}_{2}$ efflux (Fig. 5, table $\mathrm{S} 4, P=$

373 0.032), but decreased its transfer to roots, bacteria and Collembola (Fig. 5, table S4, $P=0.026$,

$3740.023,0.0048$, respectively). Drought had no impact on $\mathrm{N}$ fluxes to the plants and soil

375 communities, and only reduced ${ }^{15} \mathrm{~N}$ transfer as $\mathrm{N}_{2} \mathrm{O}$ efflux in extensively managed grassland 376 compared to the control (Fig. 5, table S4, $P=0.023$ ).

377

\section{4) ${ }^{13} \mathrm{C}$ and ${ }^{15} \mathrm{~N}$ allocation}

One day after labelling, $26 \%$ of ${ }^{13} \mathrm{C}$ fixed by plants remained in the shoots and $2.6 \%$ was recovered in the roots (Fig S6). A similar pattern was observed with the ${ }^{15} \mathrm{~N}$ tracer, for which $39 \%$ was on average recovered in the plant shoots and $12 \%$ in the plant roots (Fig S6) one day after the labelling. Intensive management decreased the ${ }^{13} \mathrm{C}$ recovery in plant roots but increased the ${ }^{15} \mathrm{~N}$ recovery in plant shoots (Fig S6, Table S5).

Analysis of ${ }^{13} \mathrm{C}$ and ${ }^{15} \mathrm{~N}$ pools revealed that in extensively managed grassland, soil fauna tended to store more photosynthesized carbon and fertiliser-derived $\mathrm{N}$ compared to intensively managed grassland (Fig S7). This pattern becomes even clearer when considering the relative allocation (Fig S6, panel C). Indeed, extensive management increased the ${ }^{13} \mathrm{C}$ recovery in $\mathrm{AM}$ fungi, detritivorous mites and predatory mites, and the ${ }^{15} \mathrm{~N}$ recovery in detritivorous mites (Fig S6, Table S5, $P<0.05$ ). Drought only decreased the recovery of the ${ }^{15} \mathrm{~N}$ in the plant roots (Fig S6, Table S5, $P<0.001$ ) and had no significant effect on the recovery of the tracers in other $\mathrm{C}$ and $\mathrm{N}$ pools (Fig S6, Table $\mathrm{S} 5, P>0.05$ ). 

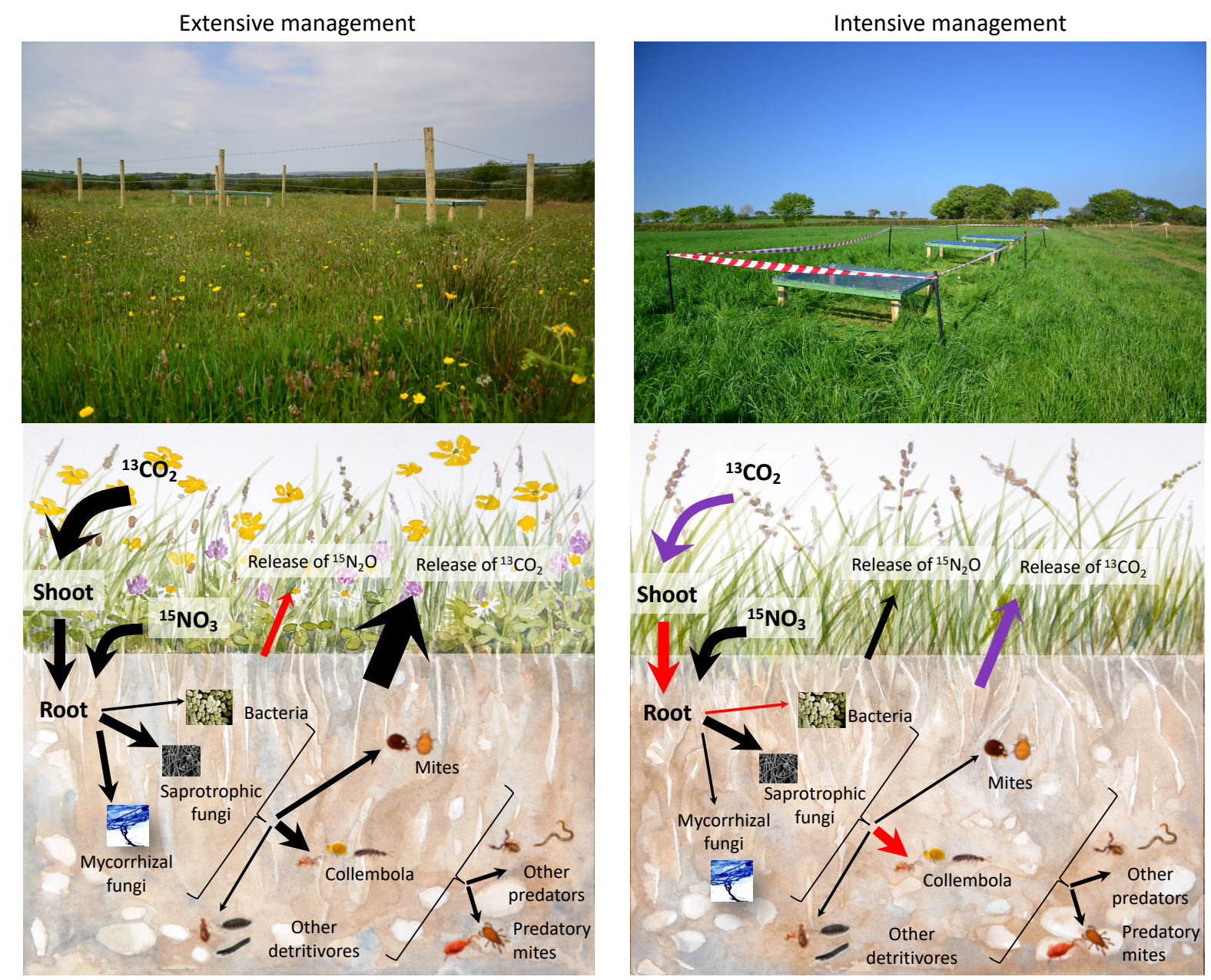

394 Figure 7. Schematic of the influence of grassland management (left panel extensive, right panel

395 intensive) and drought (negative impact in red, positive impact in violet, and no significant 396 impact in black) on ${ }^{13} \mathrm{C}$ uptake by plant shoot and transfer to roots, soil organisms and $\mathrm{CO}_{2}$ 397 efflux, and ${ }^{15} \mathrm{~N}$ transfer to $\mathrm{N}_{2} \mathrm{O}$ efflux. The size of the arrows corresponds to the relative proportion of ${ }^{13} \mathrm{C}$ or ${ }^{15} \mathrm{~N}$ incorporated by the plant, soil organisms and released as soil efflux.

399 Pictures by M. Chomel, illustrations by J. Bardgett.

\section{Discussion}

401 Our findings on the reciprocal flow of $\mathrm{C}$ and $\mathrm{N}$ through plants and soil food webs shed new 402 light on our understanding of how land management substantially modifies the response of multitrophic networks to drought, with consequences for the key ecosystem processes they regulate. We found that drought strongly affected fluxes of recent photosynthate belowground 
in the intensively managed grassland, indicating impaired resistance of this process, likely

406

407

408

409

410

411

412

413

414

415

416

417

418

419

420

421

422

423

424

425

426

427

428

429

through a decoupling of above-below ground interactions (Fig. 6). In contrast, belowground

fluxes of recent photosynthate in extensive grasslands were unaffected by drought, indicating greater potential to buffer impacts of climate extremes on above-below ground interactions.

The effect of drought on plant $\mathrm{C}$ assimilation and its allocation belowground differed between the two grassland management types. Despite decreases in aboveground biomass, drought increased plant shoot $\mathrm{C}$ uptake and decreased $\mathrm{C}$ transfer to roots in intensively managed grassland, but had no impact on these $\mathrm{C}$ transfers in extensively managed grassland.

This finding is consistent with recent reports of greater resistance and faster recovery of plants in abandoned relative to managed grasslands due to larger belowground root and fungal networks in the former, which improves water access compared to intensively managed grasslands ${ }^{19,21,46}$. In our study, the greater uptake of C by plants in intensively managed relative to extensively managed grasslands could be a compensatory effect following the release of the drought. Indeed, fast-growing plants, which dominate the plant community of intensively managed grasslands, typically have an ability to open their stomata more quickly when drought is released compared to slow-growing plant species ${ }^{47}$, which dominate the plant community in extensively managed grasslands. Our results confirmed that intensive management reduces plant diversity and promotes species with lower root-to-shoot ratio. These differences are explained by the fact that intensive management promotes fast-growing plant species, which store resources in roots to facilitate regrowth after cutting, while extensive management promotes plants that invest in root growth, rather than storage, to access soil resources ${ }^{21}$.

However, in our study, historic management intensity had no detectable effect on root ${ }^{13} \mathrm{C}$ enrichment, indicating a similar rate of root $\mathrm{C}$ allocation of newly incorporated photosynthates in both management regimes, despite large differences in their biomass allocation. 

average $5.8 \%$ of fungal $\mathrm{C}$ and $7.6 \%$ of Collembola $\mathrm{C}$ came from plant photosynthate at their enrichment peak. The high ${ }^{13} \mathrm{C}$-enrichment of non-mycorrhizal fungal PLFA compared to the

433 AM fungal PLFA is surprising, and implies an important role of non-mycorrhizal fungi in 434 channelling plant-derived $\mathrm{C}$ into the soil food web, supporting other recent findings ${ }^{48-51}$, and reflecting that saprotrophic fungi form a significant portion (20-66 \%) of microbial biomass in a grassland rhizosphere ${ }^{52}$. Although the recovery of the ${ }^{13} \mathrm{C}$ tracer was greater in bacterial PLFA compared to AM fungal or general fungal PLFA (see Fig. S5), the conversion of PLFA to biomass is higher for fungi, and this means the absolute amount of ${ }^{13} \mathrm{C}$ in bacterial biomass

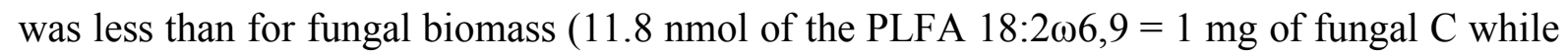

$440363.6 \mathrm{nmol}$ of total bacterial PLFA $=1 \mathrm{mg}$ bacterial $\mathrm{C}$ ). A greater proportion of plant-derived

$441 \mathrm{C}$ was recovered in AM fungi in extensively managed compared to intensively managed 442 grassland, despite similar biomass in the two systems. This pattern may be due to enhanced 443 demand or efficiency of $\mathrm{C}$ uptake by AM fungi in extensive relative to intensive managed 444 grasslands. Similar results have been found for non-mycorrhizal fungi during the course of nature restoration on abandoned arable land, where fungal biomass was not impacted, but enhanced efficiency of $\mathrm{C}$ uptake by the fungi was observed during nature restoration ${ }^{50}$. Our results show that the fungal energy channel has a more important role in extensively managed grassland and promotes the retention of recently assimilated C in soil ${ }^{19,48}$.

450 bacteria and Collembola. Collembola are more sensitive to drought than other soil fauna and 451 often reduce their grazing activity in response to drought ${ }^{29}$. Bacteria grow quickly and are more 452 sensitive to drought and other stresses than fungi ${ }^{53-58}$. Furthermore, fungi are able to create 
large hyphal networks that facilitate nutrient and water transfer over long distances, and indirectly benefit plants by exploring water-filled soil pores not accessible to plant roots ${ }^{57,59,60}$.

Our findings also indicate that soil activity (including roots and soil organisms) depends

less on $\mathrm{C}$ derived from recent photosynthate in intensively managed compared to extensively managed grasslands. This finding can be explained partially by the fact that there is less root biomass, and so less C input belowground, in intensive systems. Furthermore, our results show that there is less plant-derived $\mathrm{C}$ transfer to AM fungi and oribatid mites in intensively managed grassland, supporting the idea that intensive management modifies food web structure and decreases the flow of energy though AM fungi ${ }^{2-5,61}$. Rewetting at the end of the drought period led to an increase of respiratory losses of recent $\mathrm{C}$ from the ecosystem in intensively managed grassland. During drought, $\mathrm{C}$ pools may accumulate and become metabolically available for roots and microbes upon rewetting ${ }^{46}$. In addition, microbes can become potentially active after drought within hours upon rewetting ${ }^{62}$; they can resuscitate from dormancy ${ }^{53,63}$, and depending on the duration of drought, they can start to regrow within one to several days ${ }^{64-66}$. In extensive grassland there was marginal greater emission of ${ }^{15} \mathrm{~N}-\mathrm{N}_{2} \mathrm{O}$ (which we attribute primarily to the nitrate reducing processes of denitrification and nitrate ammonification) immediately after the ammonium nitrate was injected into the soil and during

471 the following day (Figure S3). This contradicts the general idea that intensive management of

472 soil enhances the production of $\mathrm{N}_{2} \mathrm{O}{ }^{67,68}$. This is likely to reflect the higher $\mathrm{C}$ availability in 473 extensively managed grassland providing the reductant for more sustained nitrate reduction ${ }^{69}$. 474 Moreover, in extensive grassland, drought did not modify $\mathrm{N}_{2} \mathrm{O}$ efflux, but it decreased its ${ }^{15} \mathrm{~N}-$ enrichment compared to the control (in intensive grassland, there was a significant effect at day 1 only). Soil moisture has consistently been shown to be one of the most important 
change the microbial source of measured $\mathrm{N}_{2} \mathrm{O}^{72}$. Under drought, higher concentrations of $\mathrm{O}_{2}$ in soil pores may favour ammonia oxidation of unlabelled $\mathrm{NH}_{4}$ resulting in ${ }^{14} \mathrm{~N}$-dilution of the ${ }^{15} \mathrm{~N}-\mathrm{NO}^{3}$ pool, and of the subsequent $\mathrm{N}_{2} \mathrm{O}$ emission. Surprisingly, ${ }^{15} \mathrm{~N}$ transfer to plants and soil organisms was unaffected by land management and drought, suggesting that soil driven processes of resource transfer are more buffered against perturbations compared to plant-driven processes.

\section{Conclusion}

Our findings show that intensive land management impaired the resistance of plant-derived C flow to drought, likely through a decoupling of above-below ground interactions. Moreover, our study demonstrates how the interplay between land management and climate extremes regulates bidirectional flows of nutrients through multitrophic networks. Surprisingly, grassland management and drought had little influence on the soil $\mathrm{N}$ flow, and $\mathrm{N}_{2} \mathrm{O}$ emissions were only higher after the drought in extensively managed grassland. By contrast, grassland management alters the ability of plants and soil organisms fuelled by recent photosynthate to buffer the response of $\mathrm{C}$ process to an extreme event. Our findings demonstrate that capture and rapid transfer of photosynthate through multitrophic networks is a key process for maintaining grassland resilience to drought. This highlights the need for future studies to examine trade-offs of grassland management intensities for various climate change scenarios (e.g. drought), which will identify resilient grassland management practices that can deliver sustainable food security in the face of climate change. 
502 The project was funded by a grant that formed part of the NERC Soil Security Programme (ref.

503 NE/M017028/1), which was initiated and led by RDB in collaboration with DJ, TC, FdV, EB

504 and ME. We are very grateful to the landowners and farmers for allowing us to perform our

505 experiment and sample their fields. We also thank Lucy Frotin and Juliette Papelard for help

506 in the lab and field, L. Harrold for plant and $\mathrm{N}_{2} \mathrm{O}$ isotope analysis, and B. Thornton and G.

507 Martin for the PLFA and soil fauna isotope analysis.

\section{Author contribution}

$509 \mathrm{MC}, \mathrm{JL}, \mathrm{FdC}, \mathrm{RDB}, \mathrm{DJ}, \mathrm{ME}, \mathrm{TC}, \mathrm{FdV}$ and EB conceived and designed the experiment. MC,

$510 \mathrm{JL}, \mathrm{FdC}, \mathrm{NA}, \mathrm{JR}$ and MM set-up the main experiment, MC and NA performed the pulse

511 labelling and field sampling. MM identified soil fauna, MC, NA, and HS performed laboratory

512 analyses. MC statistically analysed the data and led writing the manuscript in close consultation

513 with DJ, TC and RDB and with discussions and contributions from all authors.

\section{ORCID}

515 Mathilde Chomel 0000-0001-5110-2355

516 Jocelyn M. Lavallee 0000-0002-3028-7087

517 Jennifer M. Rhymes 0000-0001-9347-9863

518 Tancredi Caruso 0000-0002-3607-9609

519 Franciska T. Vries 0000-0002-6822-8883

520 Elizabeth M. Baggs 0000-0003-2014-2148

521 David Johnson 0000-0003-2299-2525 
Richard D Bardgett 0000-0002-5131-0127

524

\section{REFERENCES}

1. Buzhdygan, O. Y. et al. Biodiversity increases multitrophic energy use efficiency, flow and storage in grasslands. Nat Ecol Evol 4, 393-405 (2020).

2. Moore, J. C., de Ruiter, P. C. \& Hunt, H. W. Influence of productivity on the stability of real and model ecosystems. Science 261, 906-908 (1993).

3. de Ruiter, P. C., Neutel, A.-M. \& Moore, J. C. Energetics, Patterns of Interaction Strengths, and Stability in Real Ecosystems. Science 269, 1257-1260 (1995).

4. Rooney, N., McCann, K., Gellner, G. \& Moore, J. C. Structural asymmetry and the stability of diverse food webs. Nature 442, 265-269 (2006).

5. Rooney, N. \& McCann, K. S. Integrating food web diversity, structure and stability. Trends in Ecology \& Evolution 27, 40-46 (2012).

6. Bardgett, R. D. et al. Combatting global grassland degradation. Nat Rev Earth Environ 116 (2021) doi:10.1038/s43017-021-00207-2.

7. Reichstein, M. et al. Climate extremes and the carbon cycle. Nature 500, 287-295 (2013).

8. Seneviratne, S. I. et al. Weather and Climate Extreme Events in a Changing Climate. in Climate Change 2021: The Physical Science Basis. Contribution of Working Group I to the Sixth Assessment Report of the Intergovernmental Panel on Climate Change (Cambridge University Press, 2021). 
544 9. Pretty, J. et al. Global assessment of agricultural system redesign for sustainable 545 intensification. Nat Sustain 1, 441-446 (2018).

546 10. Allan, E. et al. Land use intensification alters ecosystem multifunctionality via loss of 547 biodiversity and changes to functional composition. Ecology Letters 18, 834-843 (2015).

548 11. Vályi, K., Rillig, M. C. \& Hempel, S. Land-use intensity and host plant identity 549 interactively shape communities of arbuscular mycorrhizal fungi in roots of grassland $550 \quad$ plants. New Phytologist 205, 1577-1586 (2015).

551 12. Bardgett, R. D. \& Cook, R. Functional aspects of soil animal diversity in agricultural 552 grasslands. Applied Soil Ecology 10, 263-276 (1998).

553 13. Postma-Blaauw, M. B., de Goede, R. G. M., Bloem, J., Faber, J. H. \& Brussaard, L. Soil

554 biota community structure and abundance under agricultural intensification and 555 extensification. Ecology 91, 460-473 (2010).

556 14. de Vries, F. T., Hoffland, E., van Eekeren, N., Brussaard, L. \& Bloem, J. Fungal/bacterial 557 ratios in grasslands with contrasting nitrogen management. Soil Biology and 558 Biochemistry 38, 2092-2103 (2006).

559 15. Bardgett, R. D. \& McAlister, E. The measurement of soil fungal:bacterial biomass ratios 560 as an indicator of ecosystem self-regulation in temperate meadow grasslands. Biol Fertil $561 \quad$ Soils 29, 282-290 (1999).

562 16. Bardgett, R. D., Streeter, T. C. \& Bol, R. Soil Microbes Compete Effectively with Plants for 563 Organic-Nitrogen Inputs to Temperate Grasslands. Ecology 84, 1277-1287 (2003).

564 17. Gordon, H., Haygarth, P. M. \& Bardgett, R. D. Drying and rewetting effects on soil 565 microbial community composition and nutrient leaching. Soil Biology and Biochemistry $566 \quad 40,302-311(2008)$. 
18. de Vries, F. T. et al. Extensive management promotes plant and microbial nitrogen retention in temperate grassland. PLoS One 7, e51201 (2012).

19. de Vries, F. T. et al. Land use alters the resistance and resilience of soil food webs to drought. Nature Climate Change 2, 276 (2012).

20. Ingrisch, J. et al. Land Use Alters the Drought Responses of Productivity and CO2 Fluxes in Mountain Grassland. Ecosystems 21, 689-703 (2018).

21. Karlowsky, S. et al. Land use in mountain grasslands alters drought response and recovery of carbon allocation and plant-microbial interactions. J Ecol 106, 1230-1243 (2017).

22. Duffy, J. E. et al. The functional role of biodiversity in ecosystems: incorporating trophic complexity. Ecology Letters 10, 522-538 (2007).

23. Wang, S. \& Brose, U. Biodiversity and ecosystem functioning in food webs: the vertical diversity hypothesis. Ecology Letters 21, 9-20 (2018).

24. Ruf, A., Kuzyakov, Y. \& Lopatovskaya, O. Carbon fluxes in soil food webs of increasing complexity revealed by C-14 labelling and C-13 natural abundance. Soil Biology \& Biochemistry 38, 2390-2400 (2006).

25. Pollierer, M. M., Langel, R., Koerner, C., Maraun, M. \& Scheu, S. The underestimated importance of belowground carbon input for forest soil animal food webs. Ecology Letters 10, 729-736 (2007).

26. Eissfeller, V. et al. Incorporation of plant carbon and microbial nitrogen into the rhizosphere food web of beech and ash. Soil Biology \& Biochemistry 62, 76-81 (2013).

27. Gilbert, K. J. et al. Exploring carbon flow through the root channel in a temperate forest soil food web. Soil Biology and Biochemistry 76, 45-52 (2014). 
590

591

592

593

594

595

596

597

598

599

600

601

602

603

604

605

606

607

608

609

610

611

612

613

28. Goncharov, A. A., Tsurikov, S. M., Potapov, A. M. \& Tiunov, A. V. Short-term incorporation of freshly fixed plant carbon into the soil animal food web: field study in a spruce forest. Ecological Research 31, 923-933 (2016).

29. Chomel, M. et al. Drought decreases incorporation of recent plant photosynthate into soil food webs regardless of their trophic complexity. Global Change Biology 25, 35493561 (2019).

30. Ward, S. E. et al. Legacy effects of grassland management on soil carbon to depth. Global Change Biology 22, 2929-2938 (2016).

31. Rodwell, J. S. British Plant Communities. (Cambridge University Press, 1998).

32. Cole, A. J. et al. Grassland biodiversity restoration increases resistance of carbon fluxes to drought. Journal of Applied Ecology 56, 1806-1816 (2019).

33. Buyer, J. S. \& Sasser, M. High throughput phospholipid fatty acid analysis of soils. Applied Soil Ecology 61, 127-130 (2012).

34. Frostegård, Å., Bååth, E. \& Tunlio, A. Shifts in the structure of soil microbial communities in limed forests as revealed by phospholipid fatty acid analysis. Soil Biology and Biochemistry 25, 723-730 (1993).

35. Olsson, P. A., Thingstrup, I., Jakobsen, I. \& Bååth, E. Estimation of the biomass of arbuscular mycorrhizal fungi in a linseed field. Soil Biology and Biochemistry 31, 18791887 (1999).

36. Hopkin, S. P. A Key to the Collembola (springtails) of Britain and Ireland. (FSC, 2007).

37. Krantz, G. W. \& Walter, D. E. A Manual of Acarology. (Texas Tech Universty Press, 2009).

38. Caruso, T. \& Migliorini, M. Euclidean geometry explains why lengths allow precise body mass estimates in terrestrial invertebrates: The case of oribatid mites. Journal of Theoretical Biology 256, 436-440 (2009). 
39. Ganihar, S. R. Biomass estimates of terrestrial arthropods based on body length. J. Biosci. 22, 219-224 (1997).

40. Johnson, D., Vachon, J., Britton, A. J. \& Helliwell, R. C. Drought alters carbon fluxes in alpine snowbed ecosystems through contrasting impacts on graminoids and forbs. New

$$
\text { Phytologist 190, 740-749 (2011). }
$$

41. Legendre, P. \& Gallagher, E. D. Ecologically meaningful transformations for ordination of species data. Oecologia 129, 271-280 (2001).

42. Anderson, M. J. A new method for non-parametric multivariate analysis of variance.

$$
\text { Austral Ecology 26, 32-46 (2001). }
$$

43. Anderson, M. J. Distance-Based Tests for Homogeneity of Multivariate Dispersions.

$$
\text { Biometrics 62, 245-253 (2006). }
$$

44. Zuur, A., leno, E., Walker, N., Saveliev, A. \& Smith, G. Mixed Effects Models and

$$
\text { Extensions in Ecology with R. (Springer, 2009). }
$$

45. Hedges, L. V., Gurevitch, J. \& Curtis, P. S. The Meta-Analysis of Response Ratios in

$$
\text { Experimental Ecology. Ecology 80, 1150-1156 (1999). }
$$

46. Ingrisch, J., Karlowsky, S., Hasibeder, R., Gleixner, G. \& Bahn, M. Drought and recovery effects on belowground respiration dynamics and the partitioning of recent carbon in managed and abandoned grassland. Global Change Biology 26, 4366-4378 (2020).

47. Henry, C. et al. A stomatal safety-efficiency trade-off constrains responses to leaf dehydration. Nat Commun 10, 3398 (2019).

48. Deyn, G. B. D., Quirk, H., Oakley, S., Ostle, N. J. \& Bartgett, R. D. Rapid transfer of photosynthetic carbon through the plant-soil system in differently managed species-rich grasslands. Biogeosciences (2011). 
637

638

639

640

641

642

643

644

645

646

647

648

649

650

651

652

653

654

655

656

657

658

659

660

49. Pausch, J. et al. Small but active - pool size does not matter for carbon incorporation in below-ground food webs. / 30, 479-489 (2016).

50. Morriën, E. et al. Soil networks become more connected and take up more carbon as nature restoration progresses. Nat Commun 8, 14349 (2017).

51. Li, Z. et al. The flux of root-derived carbon via fungi and bacteria into soil microarthropods (Collembola) differs markedly between cropping systems. Soil Biology and Biochemistry 160, 108336 (2021).

52. Joergensen, R. Ergosterol and microbial biomass in the rhizosphere of grassland soils. Soil Biology \& Biogeochemistry 32, 647-652 (2000).

53. Schimel, J., Balser, T. C. \& Wallenstein, M. Microbial Stress-Response Physiology and Its Implications for Ecosystem Function. Ecology 88, 1386-1394 (2007).

54. Strickland, M. S. \& Rousk, J. Considering fungal:bacterial dominance in soils - Methods, controls, and ecosystem implications. Soil Biology and Biochemistry 42, 1385-1395 (2010).

55. Manzoni, S., Schimel, J. P. \& Porporato, A. Responses of soil microbial communities to water stress: results from a meta-analysis. Ecology 93, 930-938 (2012).

56. Holden, S. R. \& Treseder, K. K. A meta-analysis of soil microbial biomass responses to forest disturbances. Front Microbiol 4, 163 (2013).

57. Guhr, A., Borken, W., Spohn, M. \& Matzner, E. Redistribution of soil water by a saprotrophic fungus enhances carbon mineralization. PNAS 112, 14647-14651 (2015).

58. de Vries, F. T. et al. Soil bacterial networks are less stable under drought than fungal networks. Nature Communications 9, 3033 (2018).

59. Allen, M. F. Mycorrhizal Fungi: Highways for Water and Nutrients in Arid Soils. Vadose Zone Journal 6, 291-297 (2007). 
661

662

663

664

665

666

667

668

669

670

671

672

673

674

675

676

677

678

679

680

681

682

683

60. Kakouridis, A. et al. Routes to Roots: Direct Evidence of Water Transport by Arbuscular Mycorrhizal Fungi to Host Plants. bioRxiv 2020.09.21.305409 (2020) doi:10.1101/2020.09.21.305409.

61. Leake, J. R., Ostle, N. J., Rangel-Castro, J. I. \& Johnson, D. Carbon fluxes from plants through soil organisms determined by field $13 \mathrm{CO} 2$ pulse-labelling in an upland grassland. Applied Soil Ecology 33, 152-175 (2006).

62. Barnard, R. L., Osborne, C. A. \& Firestone, M. K. Changing precipitation pattern alters soil microbial community response to wet-up under a Mediterranean-type climate. ISME J 9, 946-957 (2015).

63. Lennon, J. T. \& Jones, S. E. Microbial seed banks: the ecological and evolutionary implications of dormancy. Nat Rev Microbiol 9, 119-130 (2011).

64. Meisner, A., Bååth, E. \& Rousk, J. Microbial growth responses upon rewetting soil dried for four days or one year. Soil Biology and Biochemistry 66, 188-192 (2013).

65. Meisner, A., Rousk, J. \& Bååth, E. Prolonged drought changes the bacterial growth response to rewetting. Soil Biology and Biochemistry 88, 314-322 (2015).

66. Blazewicz, S. J., Schwartz, E. \& Firestone, M. K. Growth and death of bacteria and fungi underlie rainfall-induced carbon dioxide pulses from seasonally dried soil. Ecology 95, $1162-1172(2014)$

67. Baggs, E. m., Rees, R. m., Smith, K. a. \& Vinten, A. j. a. Nitrous oxide emission from soils after incorporating crop residues. Soil Use and Management 16, 82-87 (2000).

68. Le Roux, X., Bardy, M., Loiseau, P. \& Louault, F. Stimulation of soil nitrification and denitrification by grazing in grasslands: do changes in plant species composition matter? Oecologia 137, 417-425 (2003). 
684

685

686

687

688

689

690

691

692

693

694

695

696

69. Morley, N. \& Baggs, E. M. Carbon and oxygen controls on N2O and N2 production during nitrate reduction. Soil Biology and Biochemistry 42, 1864-1871 (2010).

70. Butterbach-Bahl, K., Baggs, E. M., Dannenmann, M., Kiese, R. \& ZechmeisterBoltenstern, S. Nitrous oxide emissions from soils: how well do we understand the processes and their controls? Philosophical Transactions of the Royal Society B: Biological Sciences 368, 20130122 (2013).

71. Davidson, E. A. \& Kanter, D. Inventories and scenarios of nitrous oxide emissions. Environ. Res. Lett. 9, 105012 (2014).

72. Bateman, E. J. \& Baggs, E. M. Contributions of nitrification and denitrification to N2O emissions from soils at different water-filled pore space. Biol Fertil Soils 41, 379-388 (2005). 


\section{Supplementary Files}

This is a list of supplementary files associated with this preprint. Click to download.

- Chomeletal2022.Supmat.docx 